\title{
ETHNIC SUPREMACY AND GENOCIDAL CONQUEST
}

Other instances of mass violence against non-Dinka civilians reveal a similar pattern to that of the three genocidal phases examined in this book (Juba, Unity, Central Equatoria). They illustrate how an exclusionary ideology of Dinka supremacy culminated both in military campaigns intended to kill non-Dinka civilians and in expanding Dinka conquest. I examine briefly the most salient elements below, focusing on ideology, intent, and conquest.

\section{Reflecting on other Cases of Mass Violence in South Sudan}

\section{The Perpetrators' Ideology}

Just like in Central Equatoria, this ideology revolved around Dinka group legitimacy and ownership leading to extreme group entitlement. It embraced the idea of a "master race" whose ethnic identity was primordial. From 2015 to 2017, the perpetrators manifested this exclusionary ideology of Dinka supremacy in Western Bahr El Ghazal and Upper Nile.

This ideology merged ethnic and national identities and de facto denationalizedbefore dehumanizing — members of non-Dinka groups. Just like the Nuer and the Equatorian groups, these other non-Dinka groups (such as the Balanda, the Fertit and the Shilluk) overlapped neighboring countries as well. They had not joined the SPLA en masse in the second civil war due to ethnic ranking and 
discrimination against them. As a result, they were not considered "legitimate" enough to be South Sudanese.

In Wau (in Western Bahr El Ghazal), Mathiang Anyoor troops from Aweil deployed the exact same exclusionary ideology in 2015 that was used in Western Equatoria the same year and in Central Equatoria later. "The Dinka come and take the land and say, 'Now, you've not been in the SPLA to the bush to fight, so we're taking the land," explained a Balanda civilian. "When you want to ask about this land, they'll kill you." There as well extreme group entitlement merged with exclusionary ethnic ranking: "When they have scarifications on their forehead, they say, 'When you're not cut, you're not South Sudanese.' They said this to me." In Wau too the perpetrators equated Dinka ethnicity with South Sudanese nationality.

Their delegitimization of non-Dinka civilians went together with denationalization: since no non-Dinka had truly "earned" the right to the land (shed "buckets full of human blood"), no non-Dinka was a "true" South Sudanese. ${ }^{2}$ In Upper Nile, where Dinka SPLA soldiers deployed the same supremacist rhetoric, the Shilluk knew they shared the same destiny with most non-Dinka groups: "The Dinka say that the Equatorians should go back to Uganda, Kenya, and the DRC. Also in Malakal, they say that the Shilluk should go back to Khartoum," reported a Shilluk woman. "It's the same for the Fertit (the Balanda are part of it): they should go back to Khartoum. They say the Balanda and Fertit came from Chad, and the area should remain vacant for the Dinka. The Nuer, because there are Nuer in Ethiopia, should go back to Ethiopia."3

In other words, every non-Dinka group was eventually denationalized by the Dinka perpetrators. But this was not the only similarity between all five placesUnity, Western and Central Equatoria, Western Bahr El Ghazal, and Upper Nile.

\section{The Perpetrators' Intent to Kill}

The perpetrators also seemed to intend to kill non-Dinka civilians both in Western Bahr El Ghazal and Upper Nile. As a matter of fact, in Central Equatoria perpetrators had warned civilians that genocidal violence had and would expand beyond their group. When SPLA soldiers told victims that they "wanted to kill all the people," a woman raped in March 2017 in her village in Yei county recounted, "They were talking about the entire country, not just Central Equatoria." In Wau in 2015, Mathiang Anyoor troops, mostly from Aweil, had also sought to annihilate non-Dinka civilians: "When they come, they see you, they speak Dinka, they don't ask anything, they just shoot," recalled a Balanda civilian. ${ }^{5}$

The third genocidal phase shared many commonalities with what looked like a fourth one in Upper Nile against the Shilluk. "I think that what is happening 
to the Shilluk and the Kakwa is the same," said a Shilluk woman who fled Yei. ${ }^{6}$ "Most people were slaughtered, others shot, others burned inside their houses in Malakal, Wau Shilluk, and Kodok," explained another Shilluk woman. "Slaughtered, burned, shot. Others died of lack of water." And the perpetrators were the same as in Equatoria. "The SPLA soldiers do the killing. And it is dominated by the Dinka. Those soldiers are Dinka from Lakes, Bahr El Ghazal, Jonglei."”

The victims and the vocabulary were also the same: "Whether you are a civilian, a woman, a child, they will do the same to you: they will clear you." The atrocities were incredibly reminiscent: "In Shilluk land they did the same as in Unity and Equatoria: especially the men were killed. Even the children, as long as it's a baby boy. So many women have been raped and sometimes killed.' Finally, the perpetrators worked toward the same mission: to expand their group through an annihilating and profitable conquest: "Those people have a longterm plan: they want to own all the resources ... They are raping to scare and torture-in front of your husband or on top of him-just to traumatize you so that you don't go back."

In a nutshell, civilians were witnessing a multiethnic genocide by the same group of perpetrators: "The Dinka is the biggest tribe and they take advantage of it to kill the other tribes to remove them from their lands." The guiding principle was simple (one versus all), yet the execution was challenging: if the Dinka was the biggest single group, when all other non-Dinka groups were aggregated the Dinka became the minority. Therefore, as demonstrated most in Unity, the ethnocrats had become experts at constantly co-opting members of the victim groups to blur the political landscape to outsiders and disorganize their opponents.

\section{Expanding Dinka Conquest and Dinka Groupness}

While their opponents were disorganized, the perpetrators' annihilating violence advanced Dinka conquest and fostered Dinka groupness. In Malakal (Upper Nile), after chasing most Shilluk civilians to the UN POC, Dinka settlers changed the name of the streets, just like they had in Juba. ${ }^{10} \mathrm{~A}$ Shilluk woman noted that the Dinka wives who settled with their children in the deserted houses came from different sections and subsections (clans): "After sending us away, the SPLA soldiers come with their wives and children ... They are the Dinka from Melut, Akogo, Atar. It's not only a single clan, but the Dinka tribe uniting against other tribes to extend their territory." This was a national trend, as Dinka from as far away as Bahr El Ghazal now settled on Shilluk land, across the country from their area of origin. "Even Dinka from Bahr El Ghazal come to settle on Shilluk land: from Yirol, and from Bahr El Ghazal, Warrap. Since they all speak the same language, they empower the local Dinka tribes." ${ }^{11}$ In November 2016, the 
ethnocracy even assisted about two thousand Dinka in this land rush, flying them from Juba to Malakal. ${ }^{12}$ A Dinka Padang civilian, after pointing out that Mathiang Anyoor troops were in Malakal, noted, "The Dinka are the Dinka. But many of us don't know the other Dinka. The war brought people together. But we in Upper Nile don't [didn't] know the Dinka from Bahr El Ghazal. The Dinka in Ruweng [Unity] we know, and the Dinka from Jonglei. But from Bahr El Ghazal, we didn't know." 13

While conquest fostered Dinka groupness, it also continued to reveal Dinka in-group competition. The center of gravity of military power remained firmly rooted in Bahr El Ghazal: "still, the western Dinka [from Bahr El Ghazal] were more, demographically speaking," a Bor Dinka insider noted of the SPLA's composition. ${ }^{14}$ In fact, Dinka in-group competition fueled the Dinka conquest. Mathiang Anyoor soldiers were spotted settling on the Shilluk's land, and each Dinka section defended its interests. ${ }^{15}$

This national Dinka migration and conquest, reinforcing overarching Dinka groupness when confronting non-Dinka civilians, hid an inner conquest among Dinka sections. Indeed, the western Dinka displaced other eastern Dinka civilians, especially from Bor, the rival constituency. Bor Dinka women lamented that Mathiang Anyoor troops had made it impossible for them to cultivate: "They grab the food, if you resist, they shoot you. They're scattered, not staying in one place. They've been there for almost two years. Most of them are from Bahr El Ghazal, from Warrap and Northern Bahr El Ghazal.” It was clear that the Dinka civilians from Bor, who started flooding the Ugandan refugee camps as well, were also being conquered by their rival Dinka constituency. ${ }^{16}$

The inner Dinka conquest was the prolongation of the supremacist Dinka ideology rooted in Kiir's faction: the western Dinka constituencies of Northern Bahr El Ghazal and Warrap. Symptomatically, that rival western Dinka constituency, where the Dinka hardliners mostly sprung from and then extended their reach east, was itself fractured by competition, most openly after Kiir dismissed Malong, who orchestrated violence for him from 2013 to 2017.

\section{The Wider Trends}

\section{State Coordination and Supremacist Ideology}

In every genocidal phase studied in this book, the state coordinated attacks against civilians. This violence was extremely similar in every phase. The state waged war against non-Dinka civilians. State-coordinated perpetrators lumped them into groups the state considered a threat. The perpetrators dehumanized their victims and sought to destroy them as members of their group. The perpetrators, 
including ethnic defectors in Unity state, deployed the same exclusionary ideology of Dinka supremacy.

This exclusionary ideology of Dinka supremacy linked together what might otherwise look like multiple separate instances of ethnic cleansing. This ideological thread, combined with obliterating violence, made it a genocide led by one group against all others. The ideology was rooted in the country's longue durée and the legacy of slavery in multiple ways. It was a version of extreme group entitlement, the sum of both group ownership and group legitimacy developed together during the second civil war. It had grown during the interwar period under the aegis of a growing ethnocracy supported in turn by the international community. The exclusionary ideology equated Dinka ethnic membership with South Sudanese nationality. Dinka perpetrators most fully expressed it to their victims.

This one-versus-all genocide was the result of an escalation of violence throughout all three phases since December 2013 and the Juba massacre. Each phase emboldened the state and its perpetrators, who widened the membership of the target group from the Nuer to include other non-Dinka civilians. Perpetrators lumped all of non-Dinka civilians into the category of "rebels." In equating Dinka ethnicity with South Sudanese nationality, the perpetrators denationalized their victims. From there came destruction: the victims had no right to life in South Sudan.

\section{Class, Ethnicity, and Genocide Perpetration}

Ethnic and class memberships played different roles in the implementation of each genocidal campaign. A legacy of strong ethnic ranking meant that ethnicity would take precedence over class in the perpetration of genocidal violence. Where the SPLA had a strong presence in the last war and enforced a strong system of ethnic ranking between the Dinka and other groups (as in Equatoria), it was impossible for the ethnocracy to subcontract genocidal violence via shared class interests. Members of the target group had little interest in implementing government violence. In Western and Central Equatoria, where the perpetrators were mostly Dinka, ethnicity trumped class.

But where processes of dominant class formation and in-group competition mirrored that of the Dinka ethnocrats, class won out over ethnicity in the perpetration of genocidal violence. In Unity state, processes of dominant class formation in Nuer SSDF areas similar to those in SPLA-controlled areas and ingroup competition between different Nuer sections helped the SPLA subcontract genocidal violence. The Bul Nuer especially shared more dominant class interests with the Dinka ethnocrats than with ordinary non-Bul Nuer civilians. Ethnicity 
played a role at the level of in-group competition, and genocidal violence consolidated Nuer ethnic ranking. But at the national (Dinka versus Nuer) level, class took precedence over ethnicity in co-opting Bul Nuer and other ethnic defectors and turning them into perpetrators.

Therefore, this one-versus-all genocide drew perpetrators on the basis of, alternatively, either class or ethnic membership, depending on the legacy of ethnic ranking and in-group competition, different in each location. The one constant remained that in all phases, this genocide targeted other groups defined by their non-Dinka ethnic membership. Where perpetrators were Dinka, they expressed the ethnocracy's supremacist ideology most explicitly.

\section{Violence, Conquest, and Groupness}

The supremacist ideology, combining extreme group entitlement and an essentialized vision of Dinka ethnicity as a "master race," culminated in a conquest. Group expansion through violent acquisition (of things, land, people) was the ideological extension of group entitlement. The perpetrators were merely recuperating what they thought was always theirs. In effect, supremacy went hand in hand with a profitable conquest throughout the entire country that expanded Dinka land.

Genocidal violence and conquest fostered Dinka groupness to mask in-group competition since the second civil war and the ever-narrowing ethnic center of power. Dinka perpetrators settled on the land of their victims. But this type of modern settler colonialism also hid an inner conquest among Dinka sections, whereby the land and properties of eastern Dinka sections were being taken over by their rival Dinka constituency.

\section{Becoming a Genocidal State}

How did South Sudan become a predatory and genocidal state? The short answer is that unchecked predation and strengthened group legitimacy fostered extreme group entitlement, which turned into ethnic supremacy after the second civil war. Political competition and a political crisis in 2013 provided the impetus for the ethnocratic regime to veer into genocide against non-Dinka groups. But the underlying processes of ethnicized violence and the denationalization of nonDinka had been underway since the early 1980s. Moreover, the deeper answer to this question lies in the longue durée: in the country's legacy of slavery and colonialism. The history of racist exploitation and ethnic ranking can be seen in the SPLA's discrimination against non-Dinka recruits and in its mode of production from the beginning. Unrestrained ethnic ranking and ethnically exclusive wealth 
accumulation made the formation of an ideology of Dinka ethnic supremacy possible.

An intra-Dinka coalition and proto pan-Dinka ideology of group entitlement had already emerged during the first interwar period of the 1970s. They masked Dinka in-group competition then too. As the Dinka expanded their presence, especially into Equatoria, anti-Dinka racism increased, climaxing during the kokora events - the (re)division of the South into three regions. These events were instrumental in shaping the discourse of Dinka group legitimacy within the newly created SPLA in 1983.

The predominantly Dinka SPLA reenacted interethnic hostility and the political themes of the 1970s-80s in its ranks. In practicing ethnic discrimination against non-Dinka recruits, it promoted ethnic homogeneity. Together with the performance of violence directed at ethnic outsiders, ethnic ranking steered Dinka exclusive groupness. The split of the SPLA in 1991 further ethnicized it, and the Bor massacre contributed to define the Dinka around the Bor constituency of its leader John Garang. This did not contain intra-Dinka competition, which had traversed the armed group from the start. Corruption and ethnic patronage fostered the rise of a competing Dinka political faction rooted in the northeast of Bahr El Ghazal, whose leaders would become instrumental in the third civil war.

The international endorsement of the political myth of SPLA national liberation during those years masked the armed group's ethnicization and the tensions between its two Dinka constituencies. The myth of SPLA national liberation promoted Dinka group legitimacy and resonated with the proto pan-Dinka ideology of the 1970s.

Garang's dependence on the West most likely restrained SPLA violence against civilians during the second civil war. Yet deeper processes were at work, with long-term consequences: the SPLA had started a protoconquest of non-Dinka areas while building a state (with the support of the international community) on predation. Both processes of protostate-building and protoconquest were driven by the violent, ethnically exclusionary, and exploitative SPLA's mode of (re)production. It consisted of socioeconomic and sexual predation and forced labor, while restricting control of the war economy to the preferred ethnic group. It was reminiscent of slavery's racist system of socioeconomic exploitation, which operated in part through the accumulation of women and their forced labor. As such, this mode of (re)production was prone to foster extreme ethnic group entitlement.

The SPLA's Dinka dominant class emerged through the control of this mode of (re)production, amassing and concentrating material wealth and wealth in people, expanding kinship networks, and trickling down some benefits to its 
lower strata. Through the violent accumulation of resources, people, and land, this mode of (re)production made and expanded Dinka groupness, Dinka group ownership over the territory (the protoconquest), and as such, Dinka group legitimacy.

As a result of support from the international community and aid agencies, SPLA state-making routinized and maximized predation. It benefited mostly this new Dinka dominant class. It reinforced structural inequalities based on ethnic ranking, a blueprint for the postwar ethnocracy. The increased international presence also aggravated group entitlement by reviving past humiliations from slavery and colonialism.

By 2005, SPLA nationalism largely catered to the Dinka. The international community endorsed the SPLA's predatory and exclusionary protostate through the CPA. It continued to feed it and strengthen it with aid. It supported the SPLA's usurpation of collective memory. It endorsed the violent 2010 elections and applauded the undisputed 2011 independence. Yet the international community's presence in South Sudan, in reviving racist colonial stereotypes, continued to negatively impact group worth and to irritate feelings of Dinka group entitlement.

The SPLA political myth of national liberation became the founding narrative of Dinka hardliners after Garang's death, in an international context favorable to war-mongering nationalism. Extreme group entitlement translated into an ideology of Dinka supremacy. Intraethnic competition between the two Dinka factions and against other ethnic competitors drove ethnic ranking in the state and the army.

The state turned into a violent ethnocracy under the growing influence of the hardliners from the Dinka Bahr El Ghazal faction around Salva Kiir. It eliminated Dinka dissenters through in-group policing while recruiting Dinka militias to both promote groupness and accomplish a takeover of the SPLA—and, ultimately, fully control the state. Ethnic ranking permeated society through ethnic prejudices, xenophobia, and attempts to denationalize non-Dinka groups. The past war's mode of (re)production continued in those postwar years, consolidating the conquest of non-Dinka areas, manifesting extreme group entitlement, and expanding the imagined confines of Dinka land.

The state's repression against political competitors culminated in a political crisis within the authoritarian party-state of the SPLM. The largest systematic and ethnic mass killing of Nuer by government forces in Juba on December 16, 2013, started the third civil war. The government framed this violence as a civil war and the massacre as an unfortunate side-effect of fighting. The fact that some Nuer were able to seek protection from the UN in its POC camps and that Riek Machar began a rebellion played into the government's manipulation of the "meta-conflict." The lack of international response emboldened the government. 
Settling into the houses of their victims in Juba, Dinka perpetrators continued to practice ethnically exclusive wealth accumulation-but this time preceded by annihilating violence. The Juba massacre set a precedent for the targeting of nonDinka civilians. It was the first phase of the multiethnic genocide against nonDinka civilians, which was the result of an escalation of government violence ensuing from elite decisions rooted in an ideology of ethnic supremacy.

Violence quickly transferred to oil-rich Unity state, the only Nuer-majority state of the country and home state of Machar. The government unleashed two gruesome military campaigns against Nuer civilians in 2014 and 2015, which formed the second phase of the genocide. The state coordinated and organized multiple actors to carry out attacks, subcontracting especially its second military campaign to local Nuer perpetrators who pursued their own goals of resource accumulation and group ascension. The state used the legacy of local ethnic ranking, founded on similar dynamics in both SSDF and SPLA areas in the second civil war. This had yielded a Bul Nuer version of extreme ethnic group entitlement that worked with the Dinka ethnocracy out of dominant ethnic class interests. Perpetrators implemented violence that displaced, traumatized, and destroyed the Nuer as a group. Genocidal rape helped define the perpetrators' group in multiple ways, and violent wealth accumulation continued to be ethnically differentiated.

The rippling effects of this second genocidal phase and the military build-up following the 2015 peace agreement contributed to launch the third genocidal phase in Central Equatoria. This third phase started with the fighting in Juba between IO and the SPLA July 2016. All three genocidal phases were connected by the transference of violence from one area to the next and by extremely similar acts of genocidal violence. But there was also an escalation by July 2016, based on the two previous genocidal phases and on the perceived Equatorian threat. The perpetrators of the third phase were overwhelming Dinka. The fighting in Juba in July displayed how much more exclusionary and pervasive Dinka supremacist ideology had become since December 2013. Just like in Unity, the perpetrators lumped together civilians into a group they identified as a threat to destroy.

The perpetration of violence, including mass gang-rapes, fostered the perpetrators' groupness and consolidated the ideology of Dinka supremacy. This supremacist ideology, as an expression of extreme Dinka group entitlement, naturally culminated in the idea of group expansion through acquisition, which on a large scale amounted to conquest.

In contrast to the last civil war, this conquest was accelerated and annihilating. The SPLA's ethnically exclusionary mode of production turned genocidal, with a profitable war economy. SPLA violence was no longer mostly exploitative: it was obliterating and driven by exclusionary ideology. Yet genocidal violence was still profitable, and its proceeds were distributed on an ethnic basis. 
Other instances of state military campaigns against non-Dinka civilians in Western Bahr El Ghazal and Upper Nile pointed to a similar pattern of annihilating violence, driven by the same supremacist ideology and the expansion of Dinka land. In all cases, genocidal violence fostered Dinka groupness to mask in-group competition, an ever-narrowing Dinka ethnic center of power, and an inner conquest among Dinka sections.

From the post-CPA years through this third civil war, the international community's own stereotypes about the South Sudanese and wishful thinking made it easy for the ethnocrats to remain underestimated and manipulate their former Western backers. In turn, the former backers interpreted their own failure at steering democracy in South Sudan as validation that its people were just too violent to govern themselves. They fell back on the same old colonial stereotypes inherited from military slavery and the tradition of "martial races." Yet the problem was not that the people of South Sudan were naturally aggressive and the country ungovernable. It was rather that the Western backers had sought to rid the country of its northern oppressor while supporting the rise of a predatory and violent ethnocracy. Doing so had crushed any hope for a democratic state, merely replacing one oppressor with another. 